\title{
The True Valuation of Land Use Project in China Considering Ecosystem Services
}

\author{
Man-Jing $\mathrm{Li}^{1}$, Jia-Xu $\operatorname{Han}^{1}$, Mao Zhu ${ }^{1}$ \& Yuan-Biao Zhang ${ }^{1,2,3}$ \\ ${ }^{1}$ Mathematical Modeling Innovative Practice Base, Jinan University, Zhuhai Campus, Zhuhai 519070, China \\ ${ }^{2}$ Packaging Engineering Institute, Jinan University, Zhuhai Campus, Zhuhai 519070, China \\ ${ }^{3}$ Key Laboratory of Product Packaging and Logistics of Guangdong Higher Education Institutes, Jinan \\ University, Zhuhai Campus, Zhuhai 519070, China
}

Correspondence: Yuan-Biao Zhang, Packaging Engineering Institute, Jinan University, Zhuhai Campus, Zhuhai 519070, China. E-mail: zybt@jnu.edu.cn

Received: August 29, 2019

doi:10.5539/mas.v13n10p46

\author{
Accepted: September 16, 2019 Online Published: September 17, 2019 \\ URL: https://doi.org/10.5539/mas.v13n10p46
}

\begin{abstract}
Nowadays, most land use projects disregard the impact of their decisions on the biosphere. However, they often directly affect the biodiversity and lead to environmental degradation. Considering this issue, we first select indexes from four dimensions: provisioning, regulating, supporting and culture, and establish a static ecosystem services valuation (SESV) model using equivalent factor method. Then, introducing dynamic adjustment coefficient and current discount rate, we construct a dynamic ecosystem services valuation (DESV) model, which is used to put a value on the environmental cost of land use projects. Moreover, we use entropy method to calculate the weights of the economic benefit indexes we choose and establish an economic benefit (EB) model to determine project benefit. After that, we select Canglong District Development Project in Wuhan and Three Gorges Project in China as a small community-based project and a large national project respectively to perform a cost benefit analysis using the models. As the results, compared to small-scale project, large-scale project can greatly increase the economic benefit, but at the same time, it notably increases the environmental degradation cost. Effectiveness analysis proves that the results are effective and reliable.
\end{abstract}

Keywords: ecosystem services, land use project, dynamic valuation, economic benefit, equivalent factor method

\section{Introduction}

Ecosystem services means that the biosphere provides many natural processes to maintain a healthy and sustainable environment for human life. However, land use projects often disregard the impact of their decisions on the biosphere or assume unlimited resources or capacity for their need. Cumulatively, land use projects are directly affecting the biodiversity and causing environmental degradation. Therefore, it is essential to assess the ecological services value, which contributes to analyzing the cost of environmental degradation, and account it for the cost benefit ratio of the land use project. This can determine the true and comprehensive valuation of the project and help to protect the environment to some extent.

Since ecosystem services first appeared as a term in 1981 (Ehrlich \& Ehrlich, 1981), several ecologists have carried out research on quantifying the ecosystem services value. In 1997, Costanza et al. (1997) proposed a quantitative assessment of ecosystem services value based on ecology and economics. Based on its reliable results and questionnaires filled by 200 ecologists in China, Xie Gaodi et al. (2003) improve the evaluation system of ecosystem services value by equivalent factor method, which means to construct equivalence value of various service functions of different land use types and assess them in combination with the area of land use. Besides, the method based on unit service function price can also put a value on ecosystem services value (Zhao, Ouyang, Wang, MIAO \& WEI, 2003; Zhao, Ouyang, Jia \& Zheng, 2004). Compared with the function price method, the equivalent factor method is easier to use and requires less data, which is more suitable for the assessment of the ecosystem services value at regional or global scales (Xie, Zhang, Zhang, Chen \& Li, 2015). Therefore, the equivalent factor method has been widely used. Furthermore, Wang Zhenbo et al. (2011) study the correlation and characteristics of economic development and ecosystem in the Yangtze River Delta using ESV index and EEH index. Based on the NDVI data of GIMMS remote sensing images and land use type in China 
from 1999 to 2008, Shi Yao et al. (2012) analyze the time and space changes of the China ecosystem services value in the past ten years. Ouyang Zhiyun et al. (2013) explore the application of ecosystem gross value to analyze the ecological relationships between regions and assess the effectiveness and benefits of ecological conservation.

However, at present, the equivalent factor method does not consider the impact of different time and space on the results and only gets a static value (Xie et al., 2015). For this reason, we firstly propose a dynamic ecosystem services valuation model based on the static one using equivalent factor method in order to evaluate the environmental cost of land use development projects. Besides, we establish an economic benefit model with a 14-index system to estimate the economic benefits of land use projects. Finally, we apply these models to cost-benefit analysis of different scale projects. We assume that the study regions will not occur explosive changes in the future and the equivalent value of the study area is the same as the equivalent table proposed in this paper, which make the results relatively accurate. Our models' purpose is to account for ecosystem services in the cost-benefit ratio of a project and determine the true and comprehensive valuation of the project. More importantly, it can help the planners and managers of the land use projects to plan sustainable land use development projects that are suitable for the area conditions and is beneficial to protect biodiversity and the environment.

\section{Method}

\subsection{Establishment of the Ecological Services Valuation Model}

\subsubsection{Determination of the Valuation Index and Equivalent Factor}

According to the ecosystem service classification proposed by the Millennium Ecosystem Assessment (MEA) and the ecosystem services equivalent value per unit area extracted by Xie Gaodi et al. (2015), the ecosystem services are divided into four categories: Provisioning Service, Regulating Service, Supporting Service and Cultural Service. Among them, provisioning services include agriculture production and raw material production; regulating services include air regulation, climate regulation, water regulation and waste processing; supporting services include soil purification and biodiversity; cultural services include landscape aesthetics.

Based on the research results of Xie Gaodi et al. (2015) and current land use classification (GB/T 21010-2017) in China, considering the actual situation of land use and factors such as data availability, we finally get the adjusted ecosystem services equivalent factor table as shown in Table 1.

Table 1. Ecosystem services equivalent value per unit area in China

\begin{tabular}{|c|c|c|c|c|c|c|c|c|c|c|}
\hline $\begin{array}{l}\text { Primary } \\
\text { index }\end{array}$ & $\begin{array}{l}\text { Second-class } \\
\text { index }\end{array}$ & Woodland & Grassland & Cultivated & Wetland & Garden & $\begin{array}{c}\text { Water } \\
\text { area }\end{array}$ & $\begin{array}{l}\text { Unutilized } \\
\text { land }\end{array}$ & $\begin{array}{l}\text { Industrial } \\
\text { land }\end{array}$ & $\begin{array}{l}\text { Civil } \\
\text { land }\end{array}$ \\
\hline \multirow{2}{*}{ Provisioning } & $\begin{array}{l}\text { Agriculture } \\
\text { production }\end{array}$ & 0.33 & 0.43 & 1 & 0.36 & 0.38 & 0.53 & 0.02 & 0 & 0 \\
\hline & $\begin{array}{l}\text { Raw material } \\
\text { production }\end{array}$ & 2.98 & 0.36 & 0.39 & 0.24 & 1.68 & 0.35 & 0.04 & 0 & 0 \\
\hline \multirow{4}{*}{ Regulating } & Air regulation & 4.32 & 1.5 & 0.72 & 2.41 & 2.91 & 0.51 & 0.06 & -3 & -0.5 \\
\hline & $\begin{array}{l}\text { Climate } \\
\text { regulation }\end{array}$ & 4.07 & 1.56 & 0.97 & 13.55 & 2.81 & 2.06 & 0.13 & 0 & 0 \\
\hline & $\begin{array}{l}\text { Water } \\
\text { regulation }\end{array}$ & 4.09 & 1.52 & 0.77 & 13.44 & 2.8 & 18.77 & 0.07 & -2.3 & -2 \\
\hline & $\begin{array}{c}\text { Waste } \\
\text { processing }\end{array}$ & 1.72 & 1.32 & 1.39 & 14.40 & 1.52 & 14.85 & 0.26 & -3.5 & -1 \\
\hline \multirow[t]{2}{*}{ Supporting } & $\begin{array}{c}\text { Soil } \\
\text { purification }\end{array}$ & 4.02 & 2.24 & 1.47 & 1.99 & 3.13 & 0.41 & 0.17 & 0 & 0 \\
\hline & Biodiversity & 4.51 & 1.87 & 1.02 & 3.69 & 3.19 & 3.43 & 0.40 & 0 & 0 \\
\hline Culture & $\begin{array}{l}\text { Landscape } \\
\text { aesthetics }\end{array}$ & 2.08 & 0.87 & 0.17 & 4.69 & 1.47 & 4.44 & 0.24 & 0 & 0 \\
\hline \multicolumn{2}{|c|}{ Total } & 28.12 & 11.67 & 7.9 & 54.77 & 19.89 & 45.35 & 1.39 & -8.8 & -3.5 \\
\hline
\end{tabular}




\subsubsection{Establishment of the Static Ecosystem Services Valuation Model}

According to the definition of equivalent factor, the equivalent factor table can be converted into the unit area ecosystem service value table of different land use types in the current year. It is determined that the economic value of one equivalent factor is equal to $1 / 7$ of the market value of average national grain yield per unit area in the current year. Suppose that there are $m$ types of land use in the study area, and each land use type contains $n$ types of ecosystem services value. Let $i$ represents different types of land use and $j$ represents different values of ecosystem services, and $i=1,2, \cdots, m, j=1,2, \cdots, n$.

The unit area services value of the $j^{\text {th }}$ ecosystem service in the $i^{\text {th }}$ land use is

$$
P_{i j}=F_{i j} \times \frac{v_{\text {mak }}(t)}{7}
$$

Where $F_{i j}$ is the equivalent value of the $j^{\text {th }}$ ecosystem service in the $i^{\text {th }}$ land use, $v_{\text {mak }}$ is market value of food production per unit cultivated area of the study area in the year of $t$.

The total static value of ecosystem services in the study area is the sum of the service values of all land use types, Then we introduce

$$
S E S V=(1+r)^{t-t_{0}} \times \sum_{i=1}^{m} \sum_{j=1}^{n} A_{i} P_{i j}
$$

Where $A_{i}$ is the area of $i$ type land, $(1+r)^{t-t_{0}}$ is used to discount, $r$ is the discount rate, we set it as $10 \%, t$ is the valuation year, $t_{0}$ is the base year, we set it as 2010 .

\subsubsection{Determination of Dynamic Adjustment Coefficient}

The structure and form of the ecosystem in different regions or different time periods in the same year are constantly changing, so the ecosystem service functions and their value are also constantly changing. According to the research of Hu Xisheng (2013), the dynamic assessment model should take into account the differences in space, society development stage and resource scarcity based on the static ecosystem services valuation model. In order to obtain the dynamic ecosystem services valuation model, considering the actual situation of China, we introduce spatial heterogeneity coefficient, society development coefficient and resource scarcity coefficient to improve the static model.

(1) Spatial heterogeneity coefficient

The difference of the ecological environment in different space is mainly reflected in the difference of biomass, and the ecosystem service function is closely related to the biomass. Since the biomass of woodland is the most abundant and cultivated land is the main land use type in the study area, we use the biomass of cultivated land and woodland to define the spatial heterogeneity coefficient. The formula is as follows:

$$
Q=\left(\frac{g}{G}+\frac{p l}{P L}\right) / 2
$$

Where $Q$ is spatial heterogeneity coefficient, $g$ is food production per hectare of the study area and $G$ is food production per hectare of the country, $p l$ and $P L$ are forest stock volume per unit area of the study area and the country respectively.

\section{(2) Society development coefficient}

It is pointed out that people's cognition of the ecosystem service function is a gradual process, closely related to the social economy development level (Wilson \& Carpenter, 1999). With the development of social economy, people have a deeper understanding of the ecosystem service function and their willingness to pay for the ecosystem service function will also increase. Based on this theory, we introduce the society development coefficient.

The Peel growth curve model $(\mathrm{Li}, 1999)$ can be used to represent the society development stage coefficient that varies with the social economy development, the formula is as follows:

$$
l=\frac{L}{1+e^{-\left(1 / E_{n}-3\right)}}
$$

Where $l$ is society development stage coefficient related to people's willingness to pay, $L$ is people's willingness to pay at an extremely rich stage, we set it as $1, e$ is the natural logarithm, $E_{n}$ is Engel coefficient. 
In order to show the impact of price and welfare differences in different regions on the society development level, we introduce urbanization level to adjust the Peel growth curve model, the formula is as follows:

$$
l^{\prime}=\frac{L}{1+e^{-\left(1 / E_{n}-3\right)}} \times \frac{u}{U}
$$

Where $l^{\prime}$ is adjusted society development stage coefficient, $u$ is urbanization level of the study area, $U$ is urbanization level of the country.

Assume that the ecosystem services equivalent value per unit area of the study area is the same as the equivalent value table provided in this paper. In the study area, there is no difference in people's willingness to pay for land ecosystem services. On this basis, the society development coefficient (Shi \& Wang, 2008) is constructed. The formula is as follows:

$$
D=\frac{l_{\text {study }}^{\prime}}{l_{\text {country }}^{\prime}}
$$

Where $D$ is society development coefficient of the study area, $l_{\text {study }}$ is adjusted society development stage coefficient of the study area, $l_{\text {country }}^{\prime}$ is adjusted society development stage coefficient of the country.

(3) Resource scarcity coefficient

The resource scarcity reflects the supply and demand of ecological resources in a certain area. When the demand for resources is greater than the supply, the resource scarcity occurs. The smaller the stock of ecological resources is, the greater the demand is, and the higher the resource scarcity is. Then, the greater the people's willingness to pay for the unit ecological resources is, the higher the ecosystem service value is. It means that the resource scarcity depends on the population density of the study area. Since the target of the ecosystem service is human, in this paper, we introduce population density to construct the resource scarcity coefficient. To avoid an excessive difference in results caused by this coefficient, we use the logarithm of population density to calculate. The formula is as follows:

$$
S=\frac{\log p}{\log P}
$$

Where $S$ is resource scarcity coefficient of the study area, $p$ and $P$ are the average population density of the study area and the country respectively.

\subsubsection{Establishment of the Dynamic Ecosystem Services Valuation Model}

The spatial heterogeneity coefficient, society development coefficient and resource scarcity coefficient are added to the static model to obtain the dynamic ecosystem services valuation model. The dynamic ecosystem service value of the study area in the year of $t$ is:

$$
D E S V=Q \cdot D \cdot S \cdot(1+r)^{t-t_{0}} \cdot \sum_{i=1}^{m} \sum_{j=1}^{n} A_{i} P_{i j}
$$

\subsection{Establishment of the Economic Benefit Model}

\subsubsection{Determination of the Economic Benefit Valuation Index System}

Land use economic benefit valuation of Wuhan and China focuses on the valuation of economic attributes. According to the data from 2010 to 2017, Wuhan and China's economy is developing rapidly and their industrial structure is changing. Based on the systemic principle, the comparability principle, the scientific principle and the feasibility principle, a 14-index system has been built from three aspects, which are land input intensity, output benefit and industrial structure ( $\mathrm{Li}, \mathrm{Pu}, \mathrm{Liu}, \mathrm{Fu}, \& \mathrm{Liu}, 2018)$. The valuation index system is shown as in Table 2. 
Table 2. Index in EB system

\begin{tabular}{|c|c|}
\hline $\begin{array}{l}\text { Primary } \\
\text { index }\end{array}$ & Second-class index \\
\hline \multirow{4}{*}{$\begin{array}{c}\text { Input } \\
\text { intensity }\end{array}$} & Urban fixed assets per unit area \\
\hline & Real estate development investment per unit area \\
\hline & Number of employees in the secondary and tertiary industry per unit area \\
\hline & Number of employees in urban areas \\
\hline \multirow{7}{*}{$\begin{array}{l}\text { Output } \\
\text { benefit }\end{array}$} & Added value of the industries above designated size per unit area \\
\hline & Average added value of the secondary industry \\
\hline & Average added value of the tertiary industry \\
\hline & Commercial housing sales \\
\hline & Average wage of employees in urban areas \\
\hline & Per capita consumption level of urban residents \\
\hline & Average revenue \\
\hline \multirow{3}{*}{$\begin{array}{l}\text { Industrial } \\
\text { structure }\end{array}$} & The proportion of the added value of the secondary industry in GDP \\
\hline & The proportion of the added value of the tertiary industry in GDP \\
\hline & The proportion of the added value of the industries above designated size in GDP \\
\hline
\end{tabular}

\subsubsection{Data Normalization}

Since the 14 selected indexes are all benefit types, it is no need to do data consistency processing, but we need to do nondimensionalization processing to eliminate the difference between the units of index and the difference between the magnitude. After data normalization, the data is converted to a number between 0 and 1 .

The normalized index value of the $m^{\text {th }}$ index for the $n^{\text {th }}$ evaluated objects can be calculated by the following formulas:

$$
\left\{\begin{array}{l}
X_{i j}=\frac{x_{i j}-\bar{x}_{j}}{s_{j}} \in[0,1] \\
\bar{x}_{j}=\frac{1}{n} \sum_{i=1}^{n} x_{i j} \\
s_{j}=\sqrt{\frac{1}{n} \sum_{i=1}^{n}\left(x_{i j}-\bar{x}_{j}\right)^{2}} \\
(i=1,2, \ldots, n ; j=1,2, \ldots, m)
\end{array}\right.
$$

Where $X_{i j}$ is the normalized index value, $\bar{x}_{j}$ is the average value of the $j^{\text {th }}$ index for the $n^{\text {th }}$ evaluated objects, $s_{j}$ is the mean square error of the $j^{\text {th }}$ index for the $n^{\text {th }}$ evaluated objects.

\subsubsection{Weight Model Based on Entropy Method}

Weighting model based on Entropy Method (Xie, 2014) has been widely used in the social and economic fields. The entropy value is the embodiment of information utility and using the Entropy Method to determine the weight of each valuation index can effectively avoid the influence of the error caused by the subjective weighting method. This method measures the variation degree of each index by entropy, amends the weight of each index, and finally obtains the objective weight. The specific method is as follows (Xue, Zheng, \& Wang, 2019):

Step1:

The proportion of the $j^{\text {th }}$ index in the year of $i$ is calculated as 


$$
y_{i j}=\frac{X_{i j}}{\sum_{j=1}^{m} X_{i j}}\left(0 \leq y_{i j} \leq 1\right)
$$

Step2:

Calculate the entropy using the following formula:

$$
\left\{\begin{array}{l}
e_{j}=-K \times \sum_{i=1}^{n} y_{i j} \ln y_{i j} \\
K=\frac{1}{\ln n}
\end{array}\right.
$$

The information utility value of an index depends on the distance between the information entropy of this index and 1. Its value directly affects the weight, that the greater the information utility, the greater the importance of the valuation, the greater the weight. The formula is as follows:

$$
d_{j}=1-e_{j}
$$

Step3:

Obtain the entropy weight of the $j^{\text {th }}$ index:

$$
w_{j}=\frac{d_{j}}{\sum_{j=1}^{p} d_{j}}
$$

\subsubsection{Determination of Economic Benefit}

Using the index value and the index weight, we can obtain the score of land use project in the year of $i$. The formula is as follows:

$$
S C O_{i}=\sum_{j=1}^{m} w_{j} \times X_{i j}
$$

Multiply the score by the current GDP to get the economic benefit of the project in the year of $i$ :

$$
E B_{i}=S C O_{i} \times G D P_{i}
$$

Where $G D P_{i}$ is the gross domestic product in the year of $i$.

\subsection{Establishment of the Cost-Benefit Model}

The loss of ecosystem service value caused by the land use project can be determined by the difference between ecosystem service value in the basic year and value in the year of $t$, which is as the environmental degradation cost.

$$
\triangle E S V=\left|D E S V_{0}-D E S V_{t}\right|
$$

Where $\triangle E S V$ is environmental degradation cost, $D E S V_{0}$ is dynamic ecosystem service value in the basic year, $D E S V_{t}$ is dynamic ecosystem service value in the year of $t$.

Cost-benefit ratio refers to the ratio of benefit to cost, which represents the benefit of unit cost. The higher the ratio is, the higher the efficiency of project is, and the better the project performs. Its formula is as follows:

$$
B C R=\frac{E B}{E C_{o}+\Delta E S V} \times 100 \%
$$

Where $B C R$ is cost-benefit ratio, $E B$ is economic benefit, $E C_{o}$ is economic cost, $\triangle E S V$ is environmental degradation cost.

2.4 Cost-Benefit Analysis of Large-scale and Small-scale Land Use Projects

\subsubsection{Project selection}

(1) Selection of Large-scale Land Use Project

The Three Gorges Reservoir is a national-level land use project in China, located on the upper part of the 
Yangtze River and covering 20 counties and cities of China's Hubei Province and Chongqing Municipality.

The Three Gorges Reservoir not only retains water, but also provides a strong guarantee for power generation, shipping, water supply and ecology. However, due to the large amount of floating waste and dead wood, there has been a great garbage floating patch on the river surface of the reservoir area, which affects the water quality of the reservoir and even poses a threat to the safe operation of generator sets in Three Gorges Project. Obviously, this project is a typical large-scale land use project involving ecosystem services, so we select it to evaluate the environmental degradation cost and conduct cost-benefit analysis.

(2) Selection of Small-scale Land Use Project

The Canglong Island Development Project is a small regional land use project of the Jiangxia Economic Development Project. Canglong Island, located in the east of Jiangxia District of Wuhan, consists of three peninsulas covering a total area of 45.2 square kilometers. It has convenient transportation, comfortable conditions and superior location. The government has introduced science and technology parks, educational projects, high-tech projects and real estate projects to promote the development of this economic developing zone, which is conducive to the optimization of urban structure and function adjustment in Wuhan. This has made great contributions to the economic development of Wuhan and Central China.

However, this project inevitably brought certain environmental problems in implementation process, for example, tail water discharge deteriorates the water environment of the Yangtze River, enterprise waste water directly affects the surrounding water environment, and emissions have adverse bearing on regional ambient air quality. The environmental degradation cost resulting from this project is not reflected in the benefit evaluation report. Thus, we select it as a typical small-scale land use project to evaluate the environmental degradation cost and conduct cost-benefit analysis.

\subsubsection{Cost-Benefit Analysis of Large-scale Land Use Projects}

(1) Selection of equivalent table

Since the Three Gorges Reservoir construction project, covering a wide range of areas, is a national project, the adjusted equivalent table determined in section 2.1.1 can be used directly in this section.

(2) Determination of the unit area ecosystem service value

As the scope of the study area is China, we collect the data from the China Statistical Yearbook (National Bureau of Statistics, 2010-2017). The unit area ecosystem service value of each land use type in China is calculated and shown in Table 3.

Table 3. The unit area ecosystem service value of different land use in China ( yuan $/ \mathrm{hm}^{2}$ )

\begin{tabular}{|c|c|c|c|c|c|c|c|c|c|c|}
\hline $\begin{array}{l}\text { Primary } \\
\text { index }\end{array}$ & $\begin{array}{c}\text { Second-class } \\
\text { index }\end{array}$ & Woodland & Grassland & Cultivated & Wetland & Garden & $\begin{array}{l}\text { Water } \\
\text { area }\end{array}$ & $\begin{array}{c}\text { Unutilizec } \\
\text { land }\end{array}$ & $\begin{array}{l}\text { Industrial } \\
\text { land }\end{array}$ & $\begin{array}{l}\text { Civil } \\
\text { land }\end{array}$ \\
\hline \multirow{2}{*}{ Provisioning } & $\begin{array}{l}\text { Agriculture } \\
\text { production }\end{array}$ & 510.53 & 665.24 & 1547.06 & 556.94 & 587.88 & 819.94 & 30.94 & 0.00 & 0.00 \\
\hline & $\begin{array}{c}\text { Raw material } \\
\text { production }\end{array}$ & 4610.24 & 556.94 & 603.35 & 371.29 & 2599.06 & 541.47 & 61.88 & 0.00 & 0.00 \\
\hline \multirow{4}{*}{ Regulating } & $\begin{array}{c}\text { Air } \\
\text { regulation }\end{array}$ & 6683.29 & 2320.59 & 1113.88 & 3728.41 & 4501.94 & 789.00 & 92.82 & -4641.18 & -773.53 \\
\hline & $\begin{array}{l}\text { Climate } \\
\text { regulation }\end{array}$ & 6296.53 & 2413.41 & 1500.65 & 20962.65 & 4347.24 & 3186.94 & 201.12 & 0.00 & 0.00 \\
\hline & $\begin{array}{l}\text { Water } \\
\text { regulation }\end{array}$ & 6327.47 & 2351.53 & 1191.24 & 20792.47 & 4331.76 & 29038.29 & 108.29 & -3558.24 & -3094.12 \\
\hline & $\begin{array}{c}\text { Waste } \\
\text { processing }\end{array}$ & 2660.94 & 2042.12 & 2150.41 & 22277.65 & 2351.53 & 22973.82 & 402.24 & -5414.71 & -1547.06 \\
\hline \multirow[t]{2}{*}{ Supporting } & $\begin{array}{c}\text { Soil } \\
\text { purification }\end{array}$ & 6219.18 & 3465.41 & 2274.18 & 3078.65 & 4842.29 & 634.29 & 263.00 & 0.00 & 0.00 \\
\hline & Biodiversity & 6977.24 & 2893.00 & 1578.00 & 5708.65 & 4935.12 & 5306.41 & 618.82 & 0.00 & 0.00 \\
\hline Culture & $\begin{array}{l}\text { Landscape } \\
\text { aesthetics }\end{array}$ & 3217.88 & 1345.94 & 263.00 & 7255.71 & 2274.18 & 6868.94 & 371.29 & 0.00 & 0.00 \\
\hline \multicolumn{2}{|c|}{ Total } & 43503.29 & 18054.18 & 12221.76 & 84732.41 & 30771.00 & 70159.11 & 2150.41 & -13614.12 & -5414.71 \\
\hline
\end{tabular}




\section{(3) Cost-benefit calculation method of Three Gorges Reservoir}

Collecting data from Zhang Xiaojuan (2018) and Xiong Jie et al. (2018), we know the total area of the Three Gorges reservoir area is $57335.90 \mathrm{~km}^{2}$. Multiplying the unit area ecosystem service value with the area of each land use type can get the current ecosystem services value of the project. Then, the environmental degradation cost can be obtained by making the difference between the ecosystem services value before development and the current one, is 171.42 billion yuan. By adding the economic cost, which is 180 billion yuan, to the ecological cost, we can get the true cost of the Three Gorges Project. Finally, using the models proposed above and the data collected from the China Statistical Yearbook (National Bureau of Statistics, 2010-2017), we find that the annual economic benefit, which is resulted from this project, can reach 419.05 billion yuan.

\subsubsection{Cost-Benefit Analysis of Small-scale Land Use Projects}

(1) Adjustment of the equivalent value

In order to adapt to local characteristics of Wuhan, based on the research results of Zhang Liqin et al. (2018), we take the land use and environmental conditions there into consideration and introduce the equivalent of unutilized land, industrial land and civil land. Finally, we obtain the equivalent value of Wuhan as shown in Table 4.

Table 4. Ecosystem services equivalent value per unit area in Wuhan

\begin{tabular}{|c|c|c|c|c|c|c|c|c|c|c|}
\hline $\begin{array}{l}\text { Primary } \\
\text { index }\end{array}$ & $\begin{array}{l}\text { Second-class } \\
\text { index }\end{array}$ & Woodland & Grassland & Cultivated & Wetland & Garden & $\begin{array}{c}\text { Water } \\
\text { area }\end{array}$ & $\begin{array}{l}\text { Unutilized } \\
\text { land }\end{array}$ & $\begin{array}{l}\text { Industrial } \\
\text { land }\end{array}$ & $\begin{array}{l}\text { Civil } \\
\text { land }\end{array}$ \\
\hline \multirow{2}{*}{ Provisioning } & $\begin{array}{l}\text { Agriculture } \\
\text { production }\end{array}$ & 0.25 & 0.38 & 1.16 & 0.51 & 0.31 & 0.80 & 0 & 0 & 0 \\
\hline & $\begin{array}{l}\text { Raw material } \\
\text { production }\end{array}$ & 0.59 & 0.56 & 0.21 & 0.50 & 0.57 & 0.23 & 0 & 0 & 0 \\
\hline \multirow{4}{*}{ Regulating } & Air regulation & 1.94 & 1.97 & 0.93 & 1.90 & 1.96 & 0.77 & 0.02 & -3 & -0.5 \\
\hline & $\begin{array}{l}\text { Climate } \\
\text { regulation }\end{array}$ & 5.74 & 5.21 & 0.49 & 3.60 & 5.47 & 2.29 & 0 & 0 & 0 \\
\hline & $\begin{array}{l}\text { Water } \\
\text { regulation }\end{array}$ & 3.89 & 3.82 & 1.74 & 24.23 & 3.85 & 102.24 & 0.03 & -2.3 & -2 \\
\hline & $\begin{array}{c}\text { Waste } \\
\text { processing }\end{array}$ & 1.70 & 1.72 & 0.14 & 3.60 & 1.71 & 5.55 & 0.10 & -3.5 & -1 \\
\hline \multirow[t]{2}{*}{ Supporting } & $\begin{array}{c}\text { Soil } \\
\text { purification }\end{array}$ & 2.33 & 2.40 & 0.42 & 2.31 & 2.36 & 0.93 & 0.02 & 0 & 0 \\
\hline & Biodiversity & 2.12 & 2.18 & 0.18 & 7.87 & 2.15 & 2.55 & 0.02 & 0 & 0 \\
\hline Culture & $\begin{array}{l}\text { Landscape } \\
\text { aesthetics }\end{array}$ & 0.93 & 0.96 & 0.08 & 4.73 & 0.94 & 1.89 & 0.01 & 0 & 0 \\
\hline \multicolumn{2}{|c|}{ Total } & 19.49 & 19.2 & 5.35 & 49.25 & 19.32 & 117.25 & 1.39 & -8.8 & -3.5 \\
\hline
\end{tabular}

(2) Determination of the unit area ecosystem service value

Since the study area is located in Wuhan, we collect the data from the Wuhan Statistical Yearbook (Wuhan Statistics Bureau, 2010-2017). The unit area ecosystem services value of each land use in Wuhan is calculated and shown in Table 5. 
Table 5. The unit area ecosystem service value of different land use in Wuhan ( yuan / hm ${ }^{2}$ )

\begin{tabular}{|c|c|c|c|c|c|c|c|c|c|c|}
\hline $\begin{array}{l}\text { Primary } \\
\text { index }\end{array}$ & $\begin{array}{c}\text { Second-class } \\
\text { index }\end{array}$ & Woodland & Grassland & Cultivated & Wetland & Garden & $\begin{array}{c}\text { Water } \\
\text { area }\end{array}$ & $\begin{array}{c}\text { Unutilize } \\
\text { land }\end{array}$ & $\begin{array}{l}\text { Industrial } \\
\text { land }\end{array}$ & $\begin{array}{l}\text { Civil } \\
\text { land }\end{array}$ \\
\hline \multirow{2}{*}{ Provisioning } & $\begin{array}{l}\text { Agriculture } \\
\text { production }\end{array}$ & 405.06 & 615.70 & 1879.50 & 826.33 & 502.28 & 1296.20 & 0.00 & 0.00 & 0.00 \\
\hline & $\begin{array}{c}\text { Raw material } \\
\text { production }\end{array}$ & 955.95 & 907.34 & 340.25 & 810.13 & 923.55 & 372.66 & 0.00 & 0.00 & 0.00 \\
\hline \multirow{4}{*}{ Regulating } & $\begin{array}{c}\text { Air } \\
\text { regulation }\end{array}$ & 3143.30 & 3191.90 & 1506.84 & 3078.49 & 3175.70 & 1247.60 & 32.41 & -3240.51 & -810.13 \\
\hline & $\begin{array}{l}\text { Climate } \\
\text { regulation }\end{array}$ & 9300.27 & 8441.53 & 793.93 & 5832.92 & 8862.80 & 3710.39 & 0.00 & 0.00 & 0.00 \\
\hline & $\begin{array}{c}\text { Water } \\
\text { regulation }\end{array}$ & 6302.79 & 6189.38 & 2819.24 & 39258.80 & 6237.98 & 165654.94 & 48.61 & -5346.84 & -3240.51 \\
\hline & $\begin{array}{c}\text { Waste } \\
\text { processing }\end{array}$ & 2754.43 & 2786.84 & 226.84 & 5832.92 & 2770.64 & 8992.42 & 162.03 & -5670.90 & -1620.26 \\
\hline \multirow[t]{2}{*}{ Supporting } & $\begin{array}{c}\text { Soil } \\
\text { purification }\end{array}$ & 3775.20 & 3888.61 & 680.51 & 3742.79 & 3823.80 & 1506.84 & 32.41 & 0.00 & 0.00 \\
\hline & Biodiversity & 3434.94 & 3532.16 & 291.65 & 12751.41 & 3483.55 & 4131.65 & 32.41 & 0.00 & 0.00 \\
\hline Culture & $\begin{array}{l}\text { Landscape } \\
\text { aesthetics }\end{array}$ & 1506.84 & 1555.45 & 129.62 & 7663.81 & 1523.04 & 3062.28 & 16.20 & 0.00 & 0.00 \\
\hline & ota & 31578.78 & 31108.91 & 8668.37 & 79797.59 & 31303.34 & 189974.98 & 324.05 & -14258.25 & -5670.90 \\
\hline
\end{tabular}

(3) Cost-benefit calculation method of Canglong District

The planning environmental impact report (2019) of Canglong Development District in Wuhan shows that the duration of this project is from 2011 to 2020 and its total planning area is $20 \mathrm{~km}^{2}$. Among them, the civil area accounts for $15.95 \%$, the industrial land (including land of road) accounts for $35.41 \%$ and the green land accounts for $48.64 \%$. Before the development of Canglong District, the land was barren, so we assume that its land use type was unutilized. Then, multiplying the unit area ecosystem service value with the area of each land use type can get the current ecosystem services value of the project, and the environmental degradation cost can be obtained by making the difference between the ecosystem services value before development and the current one, is 73.23 million yuan. By adding the economic cost, which is 16 billion yuan, to the ecological cost, we can get the true cost of the Canglong Development Project.

Looking up the Wuhan Statistical Yearbook (Wuhan Statistics Bureau, 2010-2017), we can get the per capita income difference, the population and the government's revenue. Using the total project income (Fan \& Gong, 2006) and the local government revenue, we can calculate the economic benefits of the project, which is about 1.45 billion yuan in times of stability every year.

\section{Results and Discussions}

\subsection{Results of Cost-Benefit Analysis}

Based on the data and models proposed in section 2, the economic cost, environmental degradation cost, economic benefits and cost-benefit ratio of the two projects can be calculated, which are shown in Table 6 .

Table 6. The cost-benefit results of two projects

\begin{tabular}{ccccc}
\hline Project Name & $E C_{o} / 10^{8}$ yuan & $\Delta E S V / 10^{4}$ yuan & EB $/ 10^{8}$ yuan & BCR/\% \\
\hline Canglong District & 160 & 7322.77 & 14.5 & 9.02 \\
Development Project & 1800 & 17141500 & 4190.5 & 119.25 \\
Three Gorges Project &
\end{tabular}

It is obvious that the environmental degradation cost and economic benefits of large-scale land use project are far larger than the small-scale one, and the cost-benefit ratio of large-scale land use project is about 13 times as much as the small-scale one. It means that large-scale land use projects are more profitable and effective, but at the same time, they cause greater damage to the environment. 


\subsection{Results of Model Change Over Time}

Our DESV model is a dynamic model varying with time and space because of the three adjustment coefficients. Spatial heterogeneity coefficient ' $Q$ ' is adjusted by the grain harvest yield and local biomass. Society development coefficient ' $\mathrm{D}$ ' is adjusted by the population density and urbanization level of the region. The population density also affects the resource scarcity coefficient ' $S$ ' to improve the accuracy of the model. Moreover, the discount rate ' $r$ ' adjusts the model with the year changed.

We take China and Wuhan as examples and collect the relevant data from 2010 to 2017 in China Statistical Yearbook (National Bureau of Statistics, 2010-2017) and Wuhan Statistical Yearbook (Wuhan Statistics Bureau, 2010-2017). Then, we replace the original economic cost of the project with the total investment in fixed assets. The $E C_{o}, D E S V$ and $E B$ of Wuhan and China for 8 consecutive years are calculated using the models we establish. The results are shown in Table 7.

Table 7. Cost-benefit indexes of Wuhan and China from 2010 to $2017\left(10^{8}\right.$ yuan $)$

\begin{tabular}{ccccccc}
\hline \multirow{2}{*}{ year } & \multicolumn{3}{c}{ Wuhan } & \multicolumn{3}{c}{ China } \\
\cline { 2 - 7 } & $E C_{o}$ & DESV & $E B$ & $E C_{o}$ & DESV & EB \\
\hline 2010 & 3753.17 & 287.37 & 1191.50 & 278121.9 & 200820 & 181114.00 \\
2011 & 4255.16 & 355.23 & 2263.95 & 311485.1 & 236780 & 208232.73 \\
2012 & 5031.25 & 444.13 & 3642.05 & 374694.7 & 285560 & 139676.81 \\
2013 & 6001.96 & 492.57 & 3854.81 & 446294.1 & 336200 & 216697.56 \\
2014 & 7002.85 & 584.26 & 5048.65 & 512020.7 & 388990 & 240873.42 \\
2015 & 7725.26 & 676.13 & 4541.16 & 561999.8 & 438550 & 281706.26 \\
2016 & 7093.17 & 601.57 & 6315.99 & 606465.7 & 449990 & 380323.94 \\
2017 & 7871.66 & 677.01 & 10427.20 & 641238.4 & 501840 & 552505.20 \\
\hline
\end{tabular}

The trends of these three cost-benefit indexes of Wuhan and China from 2010 to 2017 are shown in Figure 1 and Figure 2 respectively.

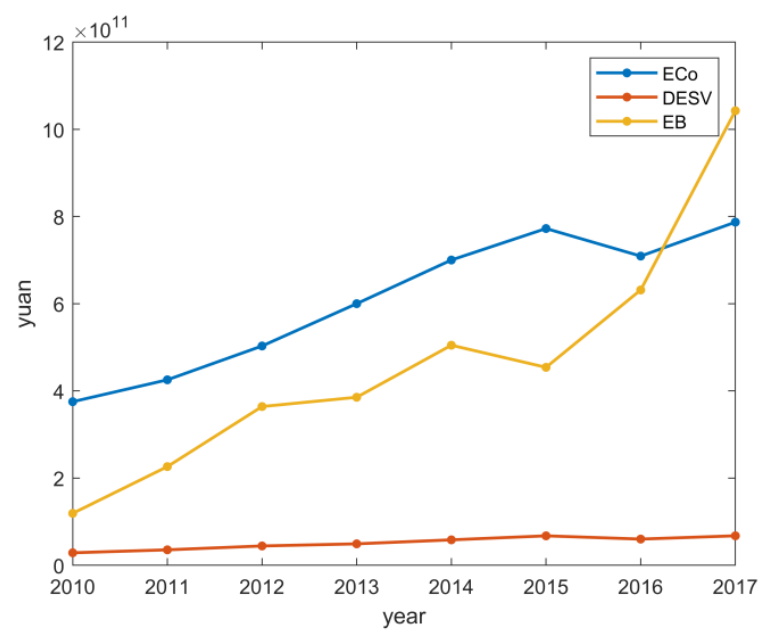

Figure 1. $E C_{o}, D E S V, E B$ of Wuhan over time

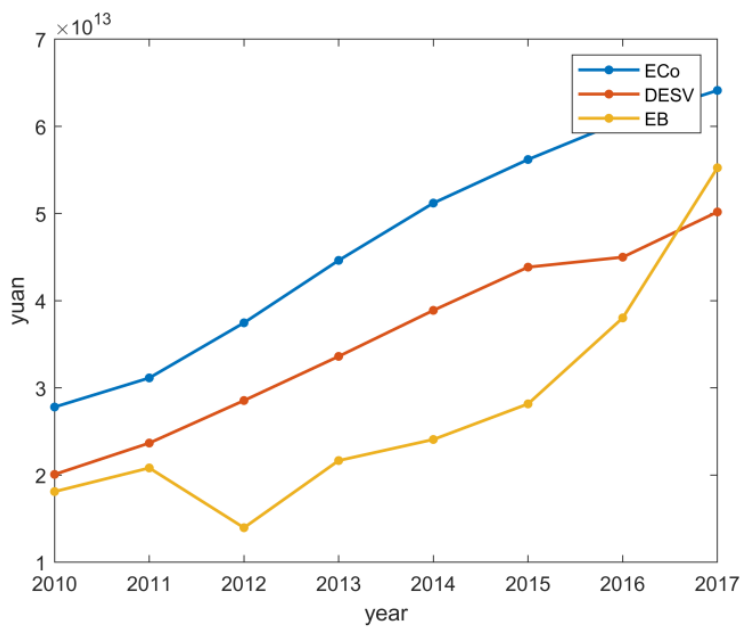

Figure 2. $E C_{o}, D E S V, E B$ of China over time

According to Table 7 and Figure1, the DESV of Wuhan maintains a mild upward trend with time, which is related to the reconstruction of wetland and green vegetation from 2010 to 2017, and the call to develop Wuhan into an international city put forward in 2012. The expansion of industrial land has also brought a stable economic growth. These are coincident with the land use plan of Wuhan. However, owing to the growth in public area, measures such as returning the grain plots to forestry have further reduced the area of cultivated land. As for China, its $D E S V$ also increase steadily over time, which is closely related to the national policy, which 
encourage us to develop the ecology and follow the road of sustainable development. The $E B$ and $E C_{o}$ of Wuhan remarkably ascend. The growth pace of $E B$ accelerates and its value exceeds $E C_{o}$ in 2016 , which is due to the introduction of high-tech, strongly improving the production efficiency of the city. If they can preferably control the ecological cost, the land use projects in Wuhan will be more optimized.

The Figure 2 shows that China's overall economic benefits dropped significantly in 2012. This is because China focuses on the development of the real economy in 2012. Then, the economic bubble, such as real estate, shrunk and led to a certain decline in overall economic benefits of China. And the years after 2012, the economic benefits bounced back rapidly because the structural adjustment had been finished. In general, China's $E C_{o}$, $D E S V$ and $E B$ all increase with year. The growth pace of $E B$ is the fastest and gradually accelerates, indicating that the national land use project performance is getting better. The growth pace of $E C_{o}$ is constant and the value of $E C_{o}$ is the largest, which means the economic cost of large-scale projects is also a problem that can not be ignored. The growth pace of $D E S V$ decreases because various environmental protection measures implemented in China are effectively compensated for the cost of the ecosystem services.

Comparing the results of these two typical examples of different scales, it can be concluded that the growth pace of the environmental degradation cost of a large-scale project is much greater than a small-scale project. Thus, we can make reasonable speculation: The environmental degradation cost of a large-scale land use project, which is consisting of small-scale land use projects, is bigger than the sum of environmental degradation cost of independent small-scale land use projects.

\section{Effectiveness Analysis}

\subsection{Sensitivity Index Model}

The effectiveness analysis of model is the basis for determining whether the model can be applied in the study area. Usually, different parameters are selected for sensitivity experiments, and each parameter is independently simulated to evaluate its impact on the results (Peng, Zhou, Yang, Zhao, \& Luo, 2014). In this paper, based on the Fenix model, which can help to analyse the sensitivity of ecosystem service value to ecosystem service value parameters per unit area (Xue \& Ge, 2018), we introduce the sensitivity index to test the availability of our model. The formula is as follows:

$$
C_{s}=\frac{\left|E S V_{j}-E S V_{i}\right| /\left|E S V_{i}\right|}{\left|V C_{j k}-V C_{i k}\right| /\left|V C_{i k}\right|}
$$

Where $C_{S}$ is sensitivity index of ecosystem service value, $E S V_{i}$ is total ecosystem service value before adjustment, $E S V_{j}$ is adjusted total ecosystem service value, $V C_{i k}$ is the unit area ecosystem service value of the $k^{\text {th }}$ land use type before adjustment, $V C_{j k}$ is the adjusted unit area ecosystem service value of the $k^{\text {th }}$ land use type. Increase the unit area ecosystem service value by 50\%, evaluate the changes of ESV and obtain sensitivity index.

When $C_{S}$ is greater than $1, E S V$ is resilient to $V C$. When $C_{S}$ is less than $1, E S V$ lacks resilience to $V C$. The larger the value of $C_{S}$ is, the more important for $E S V$ the accuracy of $V C$ value is in this kind of ecosystem .

\subsection{Results and Discussions}

Taking Wuhan as an example, we use the sensitivity analysis model, and raise the unit area ecosystem service value of forest land, grassland, cultivated land, wetland, garden land, water area, unused land and industrial land in Wuhan by $50 \%$ respectively, and finally get the sensitivity index of different land use types in Wuhan from 2010 to 2017. It can be seen from Table 8 that the sensitivity index of all land use types is less than 1 , which shows that the ecosystem service values of various land use types in this study are reasonable. 
Table 8. The sensitivity index of ecosystem service value in Wuhan

\begin{tabular}{|c|c|c|c|c|c|c|c|c|}
\hline \multirow{2}{*}{$\begin{array}{c}\text { Type of land } \\
\text { use }\end{array}$} & \multicolumn{8}{|c|}{ year } \\
\hline & 2010 & 2011 & 2012 & 2013 & 2014 & 2015 & 2016 & 2017 \\
\hline Woodland & 0.13 & 0.13 & 0.12 & 0.12 & 0.12 & 0.12 & 0.12 & 0.12 \\
\hline Grassland & 0.09 & 0.09 & 0.08 & 0.08 & 0.08 & 0.07 & 0.07 & 0.06 \\
\hline Cultivated & 0.13 & 0.13 & 0.13 & 0.13 & 0.13 & 0.13 & 0.13 & 0.14 \\
\hline Wetland & 0.12 & 0.12 & 0.12 & 0.12 & 0.12 & 0.13 & 0.13 & 0.13 \\
\hline Garden & 0.01 & 0.01 & 0.02 & 0.02 & 0.02 & 0.02 & 0.02 & 0.02 \\
\hline Water area & 0.57 & 0.58 & 0.58 & 0.59 & 0.59 & 0.60 & 0.61 & 0.61 \\
\hline $\begin{array}{l}\text { Unutilized } \\
\text { land }\end{array}$ & 0.00 & 0.00 & 0.00 & 0.00 & 0.00 & 0.00 & 0.00 & 0.00 \\
\hline $\begin{array}{c}\text { Industrial } \\
\text { land }\end{array}$ & 0.05 & 0.06 & 0.06 & 0.06 & 0.07 & 0.07 & 0.08 & 0.08 \\
\hline
\end{tabular}

The sensitivity indexes of all land use types in Wuhan from 2010 to 2017 are less than 1, which means that the selected unit area ecosystem service values have little impact on the total ecosystem service value. Thus, ESV lacks resilience to $V C$ and the results are reliable and effective.

By using this method, taking 2017 as an example, the sensitivity index is ranked from high to low as water area $>$ cultivated land $>$ wetland $>$ forest land $>$ industrial land $>$ grassland $>$ garden $>$ unutilized land. The sensitivity index of water area is 0.61 , which is the highest. When the $V C$ of the water area increases or decreases by $1 \%$, the ESV in Wuhan will increase or decrease by $0.61 \%$. This is because water area has great influence on the total ecosystem service value. On the contrary, the unutilized land has the lowest sensitivity, almost 0 , indicating that the unutilized land has little impact on the total ecosystem service value in Wuhan.

Comparing the results in 2010 with those in 2017, the sensitivity indexes of water area and industrial land show tendency to ascend. The data of water area rises from 0.57 in 2010 to 0.61 in 2017 and the data of industrial land increases from 0.05 in 2010 to 0.08 in 2017, which indicates that the impact of these two land use types on the total ecosystem service value is enlarging year by year. The sensitivity index of grassland decreases from 0.09 in 2010 to 0.06 in 2017, showing that its impact on the total ecosystem service value is diminishing year by year.

\section{Conclusions}

In order to assess the true economic costs of land use projects when ecosystem services are considered, we firstly introduce three dynamic adjustment coefficients and establish a dynamic ecosystem services valuation model. This model uses a new two-level index system, where the first level has 4 index and the second level has 9 index, and builds ecosystem services equivalent value table using equivalent factor method depending on regional characteristics. Secondly, we use the entropy method to confirm the weight of 14 land use benefit indexes and establish the project economic benefit model. Based on the DESV and EB models, we select two different-scale projects to perform cost-benefit analysis. Judging from the results, large-scale project can remarkably increase the economic benefit, but in the meantime, it cause greater harm to the environment than small-scale project. Besides, effectiveness analysis proves that the ecosystem service value of various ecosystems calculated in this study are reasonable and reliable. In conclusion, this study can provide scientific basis for quantifying environmental cost of land use project, making the valuation of land use projects more practical and promoting sustainable development.

\section{References}

Costanza, R., d'Arge, R., De Groot, R., Farber, S., Grasso, M., Hannon, B. \& Raskin, R. G. (1997). The value of the world's ecosystem services and natural capital. Nature, 387(6630), 253. https://doi.org/10.1038/387253a0

Ehrlich, P. R. \& Ehrlich, A. H. (1981). Extinction: the causes and consequences of the disappearance of species. Quarterly Review of Biology, (1), 82.

Fan, Q. \& Gong, W. (2006). Canglong Island: The past Qianlong is soaring today - to appreciate the charm of the development of Wuhan Jiangxia Canglong Island Science and Technology Park. Contemporary Economy, 
2006(10), 14-17. https://doi.org/10.3969/j.issn.1007-9378.2006.19.008

Government of Jiangxia District of Wuhan. (2019). Report on Environmental Impact Assessment of Planning and Environmental Impact of Canglong Island High-tech Industrial Park in Wuhan Jiangxia Economic Development Zone. Retrieved from http://www.jiangxia.gov.cn/gsgg/29389.jhtml

Hu, X. S., Hong, W. \& Wu, C. Z. (2013). An improved dynamic evaluation model and land ecosystem service values for Fuzhou city. Resources Science, 35(1), 30-41. Retrieved from http://kns.cnki.net//KXReader/Detail?TIMESTAMP=637038827726457500\&DBCODE=CJFQ\&TABLENa me $=$ CJFD2013\&FileName=ZRZY201301008\&RESULT $=1 \&$ SIGN=YGIwRPkpFzI4IAuN8GpzcP1pB9w $\% 3 \mathrm{~d}$

Li, J. C. (1999). Ecological value theory. Chongqing, CQ: Chongqing University Press.

Li, S. Z., Pu, C. L, Liu, X. X., Fu, W. N. \& Liu, J. Z. (2018). Evaluation on Economic Benifit of Land Use in Santai Country. Hubei Agricultural Sciences, $57(16), \quad 109-112+117$. https://doi.org/10.14088/j.cnki.issn0439-8114.2018.16.026

Ministry of Land and Resources of the People's Republic of China. (2017). Current land use classification (GB/T 21010-2017). Beijing, BJ: Standards Press of China.

National Bureau of Statistics. (2010-2017). China Statistical Yearbook 2010-2017. Beijing, BJ: China Statistics Press.

Ouyang, Z. Y., Zhu, C. Q., Yang, G. B., Xu, W. H., Zheng, H., Zhang, Y. \& Xiao, Y. (2013). Gross ecosystem product: concept, accounting framework and case study. Acta Ecologica Sinica, 33(21), 6747-6761. https://doi.org/10.5846/stxb201310092428

Peng, W. F., Zhou, J. M., Yang, C. J., Zhao, J. F. \& Luo, H. L. (2014). Research on Ecosystem Service Values Based on Land Use Change in Sichuan Province. Resources and Environment in the Yangtze Basin, 23(07), 1053-1062. https://doi.org/10.11870/cjlyzyyhj201407017

Shi, X. L. \& Wang, W. (2008). Evaluation method of integrated valuation of ecosystem functions and its application: a case study of Kangbao County, Hebei Province. Acta Ecologica Sinica, 28(8), 3998-4006. https://doi.org/10.3321/j.issn:1000-0933.2008.08.060

Shi, Y., Wang, R. S., Huang, J. L. \& Yang, W. R. (2012). An analysis of the spatial and temporal changes in chinese terrestrial ecosystem service functions. Chinese Science Bulletin, 57(17), 2120-2131. https://doi.org/10.1007/s11434-012-4978-5

Wang, Z. B., Fang, C. L. \& Wang, J. (2011). Evaluation on the Coordination of Ecological and Economic Systems and Associated Spatial Evolution Patterns in the Rapid Urbanized Yangtze Delta Region since 1991. Acta Geographica Sinica, 66(12), 1657-1668. https://doi.org/10.11821/xb201112007

Wilson, M. A. \& Carpenter, S. R. (1999). Economic valuation of freshwater ecosystem services in the United States: 1971-1997. Ecological applications, 9(3), 772-783. https://doi.org/10.2307/2641328

Wuhan Statistics Bureau. (2010-2017). Wuhan Statistical Yearbook 2010-2017. Beijing, BJ: China Statistics Press.

Xie, G. D., Lu, C. X., Leng, Y. F., Zheng, D. U. \& Li, S. C. (2003). Ecological assets valuation of the Tibetan Plateau. Journal of natural resources, 18(2), 189-196. https://doi.org/10.3321/j.issn:1000-3037.2003.02.010

Xie, G. D., Zhang, C. X., Zhang, L. M., Chen, W. H. \& Li, S. M. (2015). Improvement of the evaluation method for ecosystem service value based on per unit area. J. Nat. Journal of Natural Resources, 30(8), 1243-1254. https://doi.org/10.11849/zrzyxb.2015.08.001

Xie, Y. N. (2014). Study on Evaluation of Land Use Ecological Efficiency Based on AHP and Entropy Weight Method. Research of Soil and Water Conservation, 21(6), 134-139. https://doi.org/10.13869/j.cnki.rswc.2014.06.027

Xiong, J., Zeng, Y., Zhu, L., Zheng, Z. J., Gao, W. W., Zhao, X. F., Zhao, D. \& Wu, B. F. (2018). Land Cover Changes and Drivers in the Three Gorges Reservoir Area During 1990-2015, Resources and Environment in the Yangtze River Basin, 27(10), 2368-2378. https://doi.org/10.11870/cjlyzyyhj201810022

Xue, J. C., Zheng, H. C. \& Wang, Y. R. (2019). A Study on Land Use Benefit and Urbanization Level in Hohhot-Baotou-Ordos Region Based on Entropy Method. Bulletin of Soil and Water Conservation, 39(03), 256-262. https://doi.org/10.13961/j.cnki.stbctb.2019.03.042 
Xue, J. J. \& Ge, Y. H. (2018). Ecosystem service values in mining area of Loess Plateau:taking Xuangang mining area as an example. Journal of Shaanxi Normal University (Natural Science Edition), 46(4), 91-97. https://doi.org/10.15983/j.cnki.jsnu.2018.04.441

Zhang, L. Q., Qu, L. P., Lv, C. Y. \& Li, L. (2018). Study on Land Ecosystem Service Value in Wuhan With Spatial Structural Perspective. Resources and Environment in the Yangtze River Basin, 27(9), 1988-1997. https://doi.org/10.11870/cjlyzyyhj2018090010

Zhang, X. J. (2018). Study on the Influence of Land Use Change on the Ecological Environment Quality in the Three Gorges Reservoir Area (Master's thesis, Chongqing Technology and Business University, Chongqing, China). Retrieved from https://www.cnki.net/

Zhao, T. Q., Ouyang, Z. Y., Wang, X. K., MIAO, H. \& WEI, Y. C. (2003). Ecosystem services and their valuation of terrestrial surface water system in China. Journal of Natural Resources, 4. https://doi.org/10.3321/j.issn:1000-3037.2003.04.008

Zhao, T., Ouyang, Z., Jia, L. \& Zheng, H. (2004). Ecosystem services and their valuation of China grassland. Acta Ecologica Sinica, 24(6), 1101-1110. https://doi.org/10.3321/j.issn:1000-0933.2004.06.002

\section{Copyrights}

Copyright for this article is retained by the author(s), with first publication rights granted to the journal.

This is an open-access article distributed under the terms and conditions of the Creative Commons Attribution license (http://creativecommons.org/licenses/by/4.0/). 